\title{
Cas Wepener
}

\section{GEBED IN DIE LITURGIE: 'N PRAKTIES-TEOLOGIESE VERKENNING}

\section{ABSTRACT}

For many worshippers, prayer in the worship service is not always appropriated positively. In this article, a practical theological exploration regarding prayer in the liturgy is undertaken. By means of a spiral movement between theory and praxis, the phenomenon is scrutinised. After a description of the current practice and an attempt at explaining this state of affairs, the work of three liturgists is presented for a more normative perspective. Finally, some guidelines are formulated for a renewed theory for praxis in the light of the preceding exploration. In essence, it is argued that prayer is an essential part of the Reformed liturgy for which good preparation is essential and that a re-appreciation of the rightful place and meaning of (different forms of) prayer in the liturgy can contribute to enrich the practice for both worshippers and those leading in worship.

\section{INLEIDING}

Ten spyte van die feit dat liturge inspirerend skryf oor die betekenis van gebed in die liturgie, word dit nie altyd ewe positief deur erediensgangers toegeëien nie. In sy bekende lied "Pepermunt" sing Stef Bos hoe pepermente verligting gebring het tydens die lang en vervelige preke wat hy as kind in 'n gereformeerde erediens moes aanhoor. Vir sommige erediensgangers was die begin van die gebed ná die preek wel 'n blye tyding deurdat dit 'n seker teken was dat die preek uiteindelik verby was, maar terselfdertyd ook 'n minder blye tyding omdat 'n lang en uitmergelende gebed waarin onder andere dieselfde preek dikwels weer herhaal sou word, nog voorgelê het.

Prof. Cas Wepener, Departement Praktiese Teologie, Fakulteit Teologie, Universiteit van Pretoria. E-pos: Cas.Wepener@up.ac.za.

Acta Theologica

2012 32(1): 189-209

DOI: http://dx.doi.org/10.4314/actat.v32i1.10

ISSN 1015-8758

(C) UVIUFS

<http://www.uovs.ac.za/ActaTheologica> 
Die kernvraag wat hierdie artikel wil aanspreek is hoe die huidige praktyk van gebed in die liturgie sodanig verryk kan word dat dit vir beide voorgangers en erediensgangers meer betekenisvol kan wees. Die oogmerk is dus om roetemerkers vir 'n teorie vir die praktyk en ander praktiese voorstelle te ontwikkel. Met die oog hierop sal hierdie verkenning prakties-teologies deur ' $n$ spiraal beweeg deur te begin met die huidige praktyk, dan te kyk na enkele verklarings vir waarom dinge uitsien soos hulle tans daar uitsien, vervolgens te kyk na die dinamika of teologiese agtergrond van liturgiese gebed en ten slotte vorentoe te kyk met die oog op 'n hernude praktyk (cf. Osmer 2008). Ten einde die vraag van 'n meer betekenisvolle praktyk te beantwoord, sal die insigte wat uit die eerste drie bewegings (beskrywend empiries, interpretatief en normatief) verkry word, in die vierde pragmatiese beweging geïntegreer word met die oog op 'n beter geïnkultureerde (cf. Wepener 2009a:36-42) praktyk met betrekking tot gebed in die liturgie.

Gebed in die algemeen en gebed in die liturgie in die besonder is 'n breë veld, en teoloë vanuit 'n verskeidenheid dissiplines het al oor die onderwerp gewerk. In hierdie artikel word die kwalifisering "in die liturgie" ernstig opneem en nie alleen gekonsentreer op gebed in die liturgie nie. Slegs die werk van liturge word gebruik, en saam daarmee word veral die werk van enkele liturge wat binne die gereformeerde liturgiese tradisie aandag aan die onderwerp geskenk het, ondersoek.

\section{WAT GEBEUR TANS MET BETREKKING TOT GEBED IN DIE LITURGIE?}

'n Verkenning soos hierdie moet eerstens helderheid kry oor presies wat met "in die liturgie" as kwalifisering bedoel word. Word daarmee hoofsaaklik bedoel die erediens, met ander woorde veral dit wat liturgies in baie kerkgeboue op 'n Sondagoggend ongeveer tussen 9:00 en 10:00 gebeur? Of dui "liturgie" dít en nog meer, en kan die objek van liturgiese navorsing (Wepener 2006 \& 2009a:13-20) saam met liturge soos Marcel Barnard (2000) en Paul Post (Barnard en Post 2001) heel breed as Christelike rituele en simbole gesien word wat dus nie beperk kan word tot wat tradisioneel as "die erediens" en ander dienste bekend staan nie? Wanneer die liturgiese landskap wêreldwyd ondersoek word, is dit opvallend dat liturgie lankal nie meer tyd-ruimtelik tot slegs die laasgenoemde vieringe beperk kan word nie (cf. Wepener 2011a). Met betrekking tot gebed kan gedink word aan die sogenaamde "prayer walks" in baie gemeentes waar vry gebed as liturgiese ritueel in die strate beoefen word, die sms-gebedskettings in gemeentes, die gewildheid van meditatiewe gebedspraktyke en retraits, 
en natuurlik ook liturgiese gebed op die Internet. Met hierdie laaste voorbeeld word veral verwys na sogenaamde flitsgebede of in Engels "flash prayers" (cf. Barnard, 2006:139-142) waar mense 'n liturgiese ritueel inbou wat spesifiek fokus op gebed in hulle gewone daaglikse roetine deur gebruikmaking van die Internet. In hierdie artikel word kennis geneem van al hierdie liturgiese rituele, maar die blik word egter doelbewus heel eng gefokus. Daarvoor word vervolgens verwys na twee oorkoepelende tipes gebede en dan word twee subtipes van die tweede soort verder ondersoek.

Wanneer in die algemeen na liturgiese gebed verwys word, moet 'n onderskeid getref word enersyds tussen gebed in die liturgie waar liturgie verwys na die erediens(te) op 'n Sondag en wat dus gebede insluit wat binne daardie erediens of liturgie funksioneer, en andersyds liturgiese gebed wat kan verwys na 'n soort gebed wat liturgies van aard is, nie noodwendig in die erediens voorkom nie en anders is as vrye gebede wat gelowiges bid, byvoorbeeld tydens persoonlike stiltetyd of 'n sogenaamde "skietgebed" op enige gegewe moment. Oor die laasgenoemde soort liturgiese gebed bestaan baie bronne, byvoorbeeld die bekende werk van Taft (1993) ${ }^{1}$ in die Rooms-Katolieke tradisie en redelik $\mathrm{min}$ in die gereformeerde tradisie waarvan die werk van Diane Tripp (1996) 'n uitsondering is. In die gereformeerde tradisie sal hierdie soort "liturgiese" of dalk eerder daaglikse gebed verwys na praktyke soos tradisionele huisgodsdiens en gebed wat in die Rooms Katolieke tradisie beoefen word, onder andere daaglikse gebedstye in kloosters. Hierdie soort liturgiese gebed word egter nie in hierdie artikel behandel nie, maar slegs die eerste soort, te wete gebed in die liturgie. Hierdie sogenaamde liturgiese gebed het oor die laaste dekades egter ook gebed in die liturgie beïnvloed deurdat gebede van mense soos dié van Franciscus dikwels ook in eredienste gebid word en verskeie gemeentes meditasiedienste begin het waartydens gebede uit hierdie tradisie opgeneem word. ${ }^{2}$

Van die eerste soort liturgiese gebed, naamlik dié in die erediens, is die bekendste liturgiese tipe vaste uitgewerkte gebede wat óf spesifiek voorberei is en op skrif gestel is vir 'n spesifieke liturgie óf wat deel is van die gebedskat van die kerk. ' $n$ Tweede soort gebed wat ook in die erediens voorkom, maar eintlik as liturgiese soort gebed 'n laatkommer op die toneel is, alhoewel glad nie onbekend of vreemd in die gereformeerde liturgiese

1 Vir 'n diachroniese historiese oorsig van die wyse waarop daaglikse liturgiese gebed deur die eeue gevier is, sien Wegman (1991) wat in al die liturgiese periodes wat hy onderskei, kortliks daaraan aandag skenk.

2 Die nuutste eredienshandleiding van die NG Kerk bied 'n voorbeeld van 'n meditatiewe diens en oggend- en aandgebedsdienste (cf. Clasen et al. 2010:198-200, 249-252). 
tradisie nie, is die sogenaamde vrye gebed. Hiermee word bedoel 'n gebed in die kader van die liturgie waarvan die vorm en inhoud (dikwels) nie vooraf uitgewerk is nie, maar deur die voorganger self in die liturgie gekomponeer en geuiter word in die oomblik. Net soos vaste formuliergebede, is hierdie vrye gebed egter 'n bekende deel van gereformeerde liturgie, net soos wat die kreatiewe spanning tussen vaste liturgiese vorme en 'n vryer inkleding van die liturgie ook deels van die gereformeerde liturgiese tradisie is.

Met betrekking tot die eerste beweging van hierdie artikel, wat met betrekking tot die huidige praktyk meer beskrywend wil wees, kan opsommenderwys gesê word dat daar vloei is met betrekking tot gebed in die liturgie en dat hierdie vloei tussen verskillende liturgiese tradisies en tussen tradisionele en nie-tradisionele liturgiese ruimtes voorkom. Saam met hierdie vloei is die eeue oue kreatiewe spanning tussen vastheid en variasie met betrekking tot gebed in die liturgie steeds teenwoordig.

Indien hierdie beskrywing inderdaad iets van die huidige liturgiese landskap akkuraat beskryf, sou goedskiks gevra kon word waaraan die huidige tendense rakende gebed in die liturgie toegeskryf kan word. Vervolgens word enkele redes verken.

\section{VOORLOPIGE VERKLARING VAN DIE HUIDIGE PRAKTYK}

Die diversiteit van huidige liturgiese gebedspraktyke kan toegeskryf word aan verskeie redes wat grotendeels met sogenaamde bewegings op die ritueel-liturgiese landskap saamhang. Eerstens is daar tans 'n beweging waarin dietradisionele liturgieoorspoelvan'n beperking totslegstradisionele ruimtes na buite kerkgeboue en 'n soeke na nuwe vorme (cf Post 2010 \& 2011; Wepener 2009b \& 2011a). Hierdie beweging hang saam met verskeie ander bewegings soos ' $n$ behoefte by mense om op idiosinkratiese wyses deur liturgiese rituele aan hulle geloofslewe uitdrukking te gee. Daar is ook sprake van 'n soeke na vryheid van voorskriftelikheid deur byvoorbeeld kerkordes en eredienshandleidings wat hulle gebede met betrekking tot vorm en inhoud bepaal en natuurlik ook 'n soeke na gebedsvorme wat by nuwe of veranderende geloofsinhoude pas. Dit herinner aan die spreuk lex orandi lex credendi en hoe die wyse van aanbidding en inhoud van geloof mekaar voortdurend wederkerig beïnvloed. Deel van hierdie sogenaamde soeke na vryheid is ook ' $n$ teologiese oortuiging wat soms gehuldig word en te make het met die spanning tussen vaste liturgiese vorme en die sogenaamde vrye werking van die Gees. 
Johan van der Merwe (2009:250-253) se tien hedendaagse liturgiese skuiwe bied ook insig in hierdie verband, veral die skuif wat hy as "van dialoog na ontmoeting" beskryf en waarin hy daarop wys hoe die ekumeniese diensorde se vier bewegings gerig is op 'n ontmoeting tussen God en mens, terwyl die klassiek gereformeerde diensorde nader aan 'n gesprekmodel is en aan agendapunte kan herinner. Hierdie skuif het 'n reuse impak op liturgiese gebed deurdat die dialogiese karakter of gesprekmodel effens minder klem sal kry en gevolglik ook die vrye gebed wat veral gebid word deur slegs die predikant as beide prediker en liturg en enigste gewer van inhoud van gebede in die liturgie. Hierdie skuif wat Van der Merwe aantoon, pas binne die groter opkoms en bloei van die sogenaamde liturgiese beweging van die 19de en 20 ste eeue waartydens daar met 'n beroep op die bronne van die vroeë Kerk 'n groter ekumeniese liturgiese konsensus gegroei het, gevolglik 'n vaster ekumeniese diensorde daargestel is en veel meer bestaande gebede (weer) deel van hierdie liturgie geword het.

Soos enkele dekades gelede nog die geval was, eindig die verhaal van die liturgie in ons dag egter nie by die liturgiese beweging nie. Inteendeel, daar is sprake van ' $n$ verskeidenheid van bewegings waarvan sekere teenbewegings wel bekend is. Hier kan gedink word aan die charismatiese en Pinkstertradisies wat vryer gebede verkies, asook aan ' $n$ reaksie op die liturgiese beweging en die gepaardgaande hervorming wat daarmee geassosieer word, insluitende die liturgiese hervorming van Vatikanum II wat deur Paul Post (2004 \& 2006) die "hervorming-vandie-hervormingsbeweging" genoem word. In Rooms-Katolieke geledere is Benedictus XVI se benadering 'n goeie voorbeeld, maar ook in die gereformeerde wêreld is daar opkomende belangstelling in die klassiek gereformeerde wortels. Hierdie bewegings en teenbewegings op die liturgiese landskap het 'n invloed op hoe gebed in die liturgie daar uitsien.

Ten slotte sal verskeie ander verklarings aangebied kan word, soos die belangstelling in spiritualiteitstipes (cf. Ware 1995) en gepaardgaande pogings om liturgies meer akkommoderend te wees, ook met betrekking tot gebed. Volgens Anton Baumstark (Taft 1999) se liturgiese wetmatighede is die ossillasie in liturgiese tradisies tussen vastheid en variasie gewoon 'n gegewe in die ontwikkeling van liturgiese tradisies. Verder sal ook die diskoerse van individualisme en 'n verbruikerskultuur (cf. Stringer 2005:209-239), wat sterk vormend op erediensgangers se smaak ten opsigte van gebed en liturge se voldoening daaraan inwerk, 'n invloed uitoefen op hoe die praktyk daar uitsien. Verskeie kragte wat bepaalde invloede op die huidige praktyk uitoefen moet in ag geneem word in enige poging om die bestaande praktyk te verryk. 
Gegewe hierdie beskrywing van wat tans aangaan en enkele verklarings daarvoor, sal die geskiedenis en teologie van die onderwerp verder verken word.

\section{DRIE LITURGE OOR DIE AGTERGROND EN INHOUD VAN LITURGIESE GEBED}

\subsection{Hugh Oliphant Old}

Die gereformeerde liturgis Hugh Oliphant Old (2002:91-107) bied 'n goeie historiese oorsig oor die sogenaamde liturgiese "ministry of prayer" met gepaardgaande teologiese insigte. In 1 Kon 8:23-53 is inligting oor die wyding van die tempel in Salomo se gebed en waarvoor die tempel daargestel word. Dit is duidelik dat Salomo die tempel as 'n huis van gebed wy. Ook in Markus 11:17, waar Jesus die tempel as 'n huis van gebed vir al die nasies verstaan, word dit bevestig. In Salomo se gebed onthou hy (hesed) die verbondsbeloftes van God. Gebed en die tempel as 'n huis van gebed word hier sterk aan die verbond gekoppel. Volgens Old (2002:92) is die fondament van gebed die leer van die verbond. Nadat die verbond in herinnering geroep is, word verskeie geleenthede vir gebed in die tempel, soos droogte en militêre nederlae, geopper. Volgens Old is die veronderstelling daar dat sulke dinge gebeur omdat die volk ontrou is en hierdie gebedsgeleenthede in die tempel geleenthede van publieke en gesamentlike belydenis en vergifnis is. Old gee nog verskeie OuTestamentiese voorbeelde, maar in essensie het Salomo in gedagte gehad dat die hele nasie tydens nasionale tye van nood na die tempel kom, maar ook volgens vers 38 "luister ... na die gebed, elke smeking van enige mens" (NAV), wat daarop dui dat individue ook vir gebed na die tempel gegaan het. Die priesters was by die tempel om hierdie individue by te staan, te lei in gebed, offers namens hulle te doen en bes moontlik ook van tyd tot tyd 'n beloftewoord vir hulle te gee (Old 2002:94).

Old verwys ook na die gebed van Hanna in 1 Sam 1:1-2:11. Hier gebeur dit in die heiligdom in Silo en nie in die tempel in Jerusalem nie, maar dieselfde sou in Jerusalem kon gebeur het. Die gebed begin met die klag van Hanna wat bitterlik huil, en dan maak sy 'n gelofte in die teenwoordigheid van Eli wat in die gesprek met haar die diepe onrus in haar gemoed besef en haar dan seën en 'n profetiese woord gee. Die res van die gebeure is bekend, naamlik hoe Samuel gebore is, sy hom na Silo geneem het, 'n offer aangebied het en getuig het hoe God haar gebed verhoor het en dan 
'n "votiewe"3 dankseggingspsalm sing. Volgens Old is hierdie votief wat sy dan sing glad nie so besonder gepas vir die besondere geleentheid nie, wat beteken dat dit 'n standaard votief was en deel moes gewees het van die versameling klaggebede en ook votiewe dankseggingsgebede wat gebruiklik vir sekere geleenthede was. Bes moontlik is van tyd tot tyd 'n nuwe gebed na aanleiding van 'n spesiale geleentheid gekomponeer, maar in die algemeen is die bestaande gebedskat gebruik. So is die private gebede van individue in die gebed van Israel ingevoeg (2002:94).

Hierdie verhouding tussen private en publieke gebed in die tempel is belangrik. Die feit dat iemand na die tempel gekom het om te bid, beteken dat die persoon gepleit het dat die hele gemeenskap daardie gebed ondersteun (Old 2002:94). Ook in die Psalms wat fokus op die persoon van die koning en die intrede vir die koning en sy welsyn was inderdaad intersessie-gebede vir die hele volk. Oor Dawid en gebed in die Psalms skryf Old: "David prayed for Israel and Israel prayed for David; even more Israel prayed in David." Volgens Old is dit die rede waarom so baie Psalms opskrifte het wat die lewensomstandighede van Dawid weergee waarbinne die gebed gebore is. Hierdie idee is verder geneem in Handelinge waar Dawid as ' $n$ tipe Christus gesien is.

The Christian prays in the name of Jesus, Christ prays for the church, and the church prays in Christ. One thing this means is that the Christian inserts his or her own prayers into the prayer of Christ. Another thing it means is that the Christian appropriates the prayer of Christ. The ascended Christ at the right hand of the Father intercedes for the church and presents our individual prayers at the throne of grace, as part of his own prayers. Our prayer mingles with the sweet incense of his prayer (Old 2002:95).

Die gebed van die sinagoge het anders ontwikkel as die gebed van die tempel (Old 2002:95-96). Die gebed was die sogenaamde Amida (wat beteken "om te staan") wat Jesus en sy apostels bes moontlik gevolg het. Daar was 18 dele in die gebed waarvan die inhoud nie vas was nie, maar die rangskikking en die temas was redelik standaard. Wanneer 'n rabbi in hierdie Amida voorgegaan het, was verwag dat hy op die temas sou voortborduur. Breedweg het die gebed bestaan uit drie bede vir danksegging en lof, gevolg deur ses versoeke of petisies, daarna ses intersessies vir die welstand van Israel en ten slotte drie dankseggings en seëninge wat eindig met die Aäronitiese seën. Belangrik is om te sien hoe die voorbidding en intersessies deur lof en danksegging omvou word. Die Amida word deur Jesus gekritiseer, veral met betrekking tot die wyse waarop sommiges dit gebid het, alhoewel Jesus bes moontlik die vorm

"Ten opsigte van 'n gelofte" 
self gebruik het om ook die Ons Vader-gebed op te skoei. Indien die laaste doksologie van die Ons Vader-gebed byvoorbeeld wel oorspronklik is, begin en eindig beide met lof en danksegging met petisies in die middel. Volgens Old kan die Ons Vader met betrekking tot vorm deurgaan as 'n baie kort Amida. Jesus het egter sekere dele van die Amida doelbewus verander, byvoorbeeld die feit dat die Amida geen voorbidding bevat vir die heidene of die vervolgers van Israel nie, maar vir die verlossing van Israel alleen, terwyl Jesus sy dissipels doelbewus anders geleer het.

Hierdie laaste beginsel word verder geneem met Paulus waar hy vir Timoteus opdrag gee om toe te sien dat die gebed van die kerk gebede vir alle mense insluit, ook vir konings en selfs vir die heidense regeerders van die wêreld. Paulus argumenteer hier dat God se wil die verlossing van alle mense is, en daarom moet daar sodanig gebid word (cf. 1 Tim. 2:1-4 en Old 2002:97). Dikwels vra Paulus ook dat spesifieke sake in die voorbidding van gemeentes ingesluit word en noem self hoe hy in sy eie gebede aan spesifieke mense en sake dink.

Enkele opmerkings oor liturgiese gebed in die eeue daarna kan ook verhelderend wees. Volgens Justinus die Martelaar was die intrede-gebed ná die preek en voor die Nagmaal in die eerste helfte van die 2de eeu ' $n$ integrale deel van die liturgie wat staande gebid is (Old 2002:98-99). Teen die einde van die 4de eeu in die Apostoliese tradisie was die groot intersessie-gebed 'n standaard deel van die liturgie. Hier sluit die gebed intrede in vir die wêreldkerk, die plaaslike gemeente, die bediening, die plaaslike biskop, ouderlinge, diakens en ander leiers in die kerk, getroude mense, selibate persone, verwagtende vroue, siekes, uitgeworpenes, diegene in die tronk, vyande, die vervolgers van die kerk en dié wat nie aan die kerk behoort nie (Old 2002:99). Duidelik het die tradisie van die Amida en Jesus se leer hier vervloei en is dit opmerklik dat die aard van die gebed besonder inklusief is. Hierdie groot intersessie-gebed het so te sê in die liturgie van die Middeleeue verdwyn. Onder invloed van die teologie van die dag het die klem in liturgiese gebed algaande na die verkryging van 'n soort eenheid met God verskuif en was die fokus heelwat minder op praktiese sake van die lewe. Verder het gebed begin ontwikkel as 'n medium om van die materiële wêreld te ontsnap (Old 2002:99).

Die Reformasie het 'n radikale hervorming van publieke gebed gebring, wat veral op die bestudering van gebed in die Skrif gebaseer was. Dit het ook as ' $n$ model gedien, en nuwe gebedsvorme is ontwikkel. In Straatsburg het byvoorbeeld twee hooftipes ontwikkel, naamlik 'n gebed om skuldbelydenis en 'n intrede-gebed of voorbidding. Hierdie gebede is sterk op die Psalms geskoei. So het die standaard patroon van skuldbelydenis, versoek om vergifnis, 'n genadeverkondiging en uiteindelik 
'n dankseggingspsalm wat deur die gemeente gesing word, ontwikkel. Saam hiermee het die intersessiegebed ook ontwikkel, en in Bucer se gebed is daar intrede vir die burgerlike regering, die bediening van die Evangelie, die heiligmaking van die gelowiges en vir dié wat swaarkry (Old 2002:100). Onder die invloed van Calvyn is hierdie twee gebede ook deel van die aanbidding in Genève gemaak, en sedertdien het hierdie twee gebede twee kerndele van gereformeerde aanbidding geword. ${ }^{4}$ Calvyn se eie eerste twee onderskeidende tipes publieke gebed is volgens Brienen (1987:186) gebed met gesproke woorde en gesonge gebed.

Gelyklopend in hierdie era het ook 'n tradisie ontstaan waar die predikant gewoonlik in die liturgie 'n vrye gebed gebid het. Volgens Calvyn kan daar nie van alle predikante verwag word om die gawe te hê om in gebed voor te gaan nie. Self het hy die gebed om skuldbelydenis en intrede-gebed uit 'n boek gebid, maar ná sy preke het hy wel vrye gebede gebid waarvan heelwat vir ons behoue gebly het. Volgens Calvyn lei die hoor van God se Woord natuurlik tot gebed. Volgens Old (2002:100-101) het Calvyn deur hierdie gebede vanaf die Woord na die wêreld beweeg. Die prediking het dus hierdie gebed beide opgeroep en gevorm. Hoe dit ook al sy, soos reeds genoem, is hierdie gebed ná die preek voorafgegaan deur 'n meer introspektiewe gebed van skuldbelydenis en verootmoediging, wat "doop"-gebede is, en die intrede-gebed wat meer uitwaarts tot die wêreld gerig is weer "Nagmaal"-gebede is. Brienen (1987:186-187) wys weer op Calvyn se nadruk daarop dat gebed in die liturgie "met hart en siel" moet geskied. Dit was egter nie 'n argument ten gunste van vrye gebed nie, maar eerder dat mense met aandag en in geloof sal bid. Brienen stel dit as volg: "Daarvoor acht Calvijn het uitgeschreven, het formuliergebed, beter geschikt dan het vrije gebed, al verbiedt hij dit nergens."

Wat die liggaamshouding tydens gebed in die liturgie betref, het Calvyn volgens Brienen (1987:194; sien ook Tripp 1996:15) op verskeie plekke sy voorkeure uitgespreek. Hy het naamlik kniel tydens gebed in die liturgie aangemoedig as ' $n$ teken van eerbied en nederigheid, dat mans hul hoofde tydens gebed ontbloot en dat die opheffing van hande tydens gebed 'n ware Bybelse gebaar is ${ }^{5}$. Bes moontlik weens Calvyn se vrese vir bygeloof

4 Vir meer besonderhede oor die verskillende tipes gebed in die liturgie by Calvyn, sien Brienen (1987:187-194).

5 Met betrekking tot gebare tydens gebed sou in besonderhede ingegaan kon word, afhangende van die presiese plek waar die aanbidding plaasgevind het. Tripp (1996:15) wys byvoorbeeld daarop dat in 19de-eeuse Franse gereformeerde eredienste lidmate gestaan het vir gebed en gesit het vir lofsang; in sekere plekke het vrouens ook ooswaarts gedraai tydens gebed en was daar byvoorbeeld ook die sogenaamde "coif" wat deur vrouens in Basel tot en met die 19de eeu gebruik is. Dit het beteken dat hierdie "coif" sodanig gevou is dat 
tydens die Nagmaal soos die aanbidding van die hostie en afwysing van kniel daar het die gebruik grotendeels in die gereformeerde liturgiese tradisie verlore geraak.

In die puriteinse era het die Westminster Directory for Worship die lang gebed wat Calvyn ná die preek gehad het, voor die preek en ná die Skriflesing geplaas. Volgens Old (2002:102-103) was dit 'n ongelukkige ontwikkeling omdat dit onuithoudbaar lank was, die tradisionele orde wat liturgies bykans logies by die tafel gepas het, verbreek het en dat dit sy karakter verloor het deur 'n algemene, meerdoelige gebed te word. In die tyd van die piëtisme het gebed meer spontaan geword, en erediensgangers is aangemoedig om hulle gebede en versoeke te opper. Kleiner gebedsgroepe is georganiseer. Die vooraf goed voorbereide gebed het grootliks weggeval en die gedagte het ontstaan dat diegene wat werklik deur die Heilige Gees vervul is, nie vir gebed in die liturgie hoef voor te berei nie (Old 2002:104). Werk en gebed gaan ook hand aan hand, daarom het die Morawiërs heeldag lank gesing en gebid terwyl hulle gewerk het. Onder hulle invloed het John Wesley ook hierdie tradisie van klein gebedsgroepe oorgeneem. Die Metodistiese tradisie het daaruit ontwikkel, en die piëtistiese gebedsvorme het die Amerikaanse Protestantisme en liturgiese gebed sterk beïnvloed. Ten slotte kan verwys word na Benjamin Palmer, 'n Amerikaanse Presbiteriaanse predikant, en sy boek oor gebed getiteld Theology of Prayer. Histories saamgevat, beskou hy daarin die Gereformeerde gebed as 'n liturgiese aktiwiteit wat trinitaries verstaan kan word as die werk van die Gees, in die liggaam van Christus tot eer van die Vader (Old 2002:106-107).

\subsection{Gerrit Immink}

In sy nuwe boek oor die liturgie, Het heilige gebeurt. Praktijk, theologie en traditie van de protestantse kerkdienst, brei die Gereformeerde homileet en liturgis van die PThU, Gerrit Immink, uit oor gebed in die liturgie. Soos wat die bidder sigself tot God rig, so rig God Hom op 'n analogiese wyse tot die wêreld (Immink 2011:183). Dikwels is aspekte soos vertroue daarop dat die wêreld uiteindelik aan God se liefdeswil onderworpe is, vir mense vaag. Sodra mense egter tot die aksie van gebed oorgaan, kom hierdie soort aspekte wel in die spel. In gebed rig die mens haar tot die persoonwees van God en die persoon van God is gerig op die wêreld en werksaam betrokke by die wêreld (Immink 2011:184). Volgens Immink is gebed dus veranker in die mens se strewe na geluk en moet daar meer wees as hoe

slegs vrouens se neuse uitgesteek het en die materiaal agter tot in die middel van hulle bene afgehang het. 
sake tans daar uitsien. Met verwysing na die werk van Gert Otto, wys Immink daarop dat gebed 'n plek tussen klag en verlange het.

Verder wys Immink daarop dat gebed ook op ander wyses kan funksioneer, byvoorbeeld as 'n hantering of "coping"-strategie. So is daar ' $n$ verband tussen die liturgiese gebede en die verlange van kerkgangers wat hulle lewens voor God tot uitdrukking bring. Volgens Immink bied die kerk vir hierdie behoefte van mense godsdienstige kapitaal deurdat die liturgie byvoorbeeld help dat die gemoedslewe beheers ontvou soos in 'n kerklied wat ' $n$ kanaliserende funksie kan hê. In verband hiermee haal Immink vir Peter Brunner aan, volgens wie die vraag of die predikant met die gemeente op 'n goeie wyse bid net so belangrik is soos die vraag of die predikant goed preek (2011:186). Lidmate se eie persoonlike gebedslewe is dikwels nie goed gevarieerd nie en bestaan dikwels uit nie veel meer as die vraag-vorm van gebed nie. Juis in hierdie opsig is die ryke verskeidenheid van gebedsmodi in die liturgie waardevol. Dit vergroot die kerkganger se spyskaart met betrekking tot gebed heelwat. Juis in ons eie dag is daar 'n geneigdheid tot slegs die vraag-vorm, terwyl danksegging teologies beskou aldus Immink die kern van kerk se gebedspraktyk moet vorm. Juis in hierdie verband het die liturgie en gebed in die liturgie 'n belangrike rol om te vervul.

Immink wys verder op die spanning tussen gebede met 'n vaste vorm en vry gebed in die liturgie binne die gereformeerde tradisie. Hy haal onder andere vir Willem Barnard aan, wat die geïmproviseerde gebed as "hachelijk, vaak honds en brutaal" beskou, maar ook vir Abraham Kuyper wat volgens hom die spanning tussen vaste vorm en vrye gebed in die Gereformeerde tradisie goed ingesien het vanweë die nadruk op die werk van die Heilige Gees. Ook Elsie Ann McKee bevestig hierdie punt deur daarop te wys hoe belangrik dit vir Calvyn was dat gebed in die liturgie weer in die monde van die versamelde gemeente geplaas word, maar dat die woorde van die tekste inderdaad gepas moet wees (McKee 2003:19).

As 'n onderdeel van deel II in die boek behandel Immink (2011:77-82) "de bede om de Heilige Geest (epiclese)". Die epiklesegebed voor die Skriflesing en prediking en voor die Nagmaal het 'n sterk pneumatologiese karakter deurdat die aanwesigheid van Christus afgesmeek en verwag word, alhoewel Immink (2011:78) dit benadruk dat laasgenoemde nie afgedwing kan word nie; daarom lê hy die nadruk daarop dat dit in die epiklese om die toeganklikheid en ontvanklikheid van die mens gaan. Die Heilige Gees verlig beide die verstande en die harte van die hoorders sodat die Woord in die mens kan werk. Dit is dus duidelik dat die epiklese ' $n$ sentrale rol in gereformeerde teologie en gevolglik ook begrip van die erediens speel. Hierdie nadruk op die epiklese sal in lyn wees met Dirkie 
Smit (2009:87-107) se begrip van die gereformeerde erediens naamlik dat dit uiteindelik gaan oor die aard van God se teenwoordigheid, die aard van die teenwoordige God en die aanbidding van die teenwoordige God. Soos Immink (2011:82) dit duidelik stel, "De epiclese duidt op een diep besef van receptiviteit."

\subsection{Julian Müller}

In sy boek oor die erediens getiteld Die erediens as fees (1990), wat met die Andrew Murray-prys bekroon is, behandel Müller gebed as een van die sogenaamde hoekstene van die erediens onder die opskrif "Die antwoord van die gemeente" saam met geloofsbelydenis, offergawes en antwoordlied. Hy maak 'n sterk koppeling hier "aan die einde van die erediens" tussen die sogenaamde liturgie van die erediens en liturgie van die lewe waarin liturgiese gebed 'n soort brugfunksie vervul (Müller 1990:94-95). Müller ondersoek hier spesifiek die sogenaamde voorbiddingsgebed wat meer na buite gerig is op die wêreld en wat wel ander elemente soos lof sal bevat, maar waarvan die hoofklem wel voorbidding is. Hierdie intredegebed is 'n deelname van die gemeente aan die priesterlike amp van Christus (Müller 1990:95) en dus, soos hy dit goed verduidelik, "die gemeente wat bid vir dié daarbuite". Hierdie aksente wat Müller lê, resoneer sterk met beide Old en Immink se nadenke oor liturgiese gebed en selfs ook met 'n liturgis soos Van Tongeren (2001; sien ook Wepener \& Cilliers, 2004) wat die verband tussen lex orandi lex credendi in die lig van sy nadenke oor liturgiese gebed uitbrei na lex vivendi. Müller se begrip van voorbidding in die liturgie laat hom dan ook 'n pleidooi lewer ten opsigte van die praktiese liturgiese toepassing van hierdie begrip deur op misverstande te wys, beter voorbereiding van gebed in die liturgie, aanmoediging van groter betrokkenheid van meer lidmate daarby en laastens ook 'n doelbewuste program vir voorbidding (cf. Müller 1990:95-99).

\section{GEBED IN DIE LITURGIE: ENKELE ROETE- MERKERS EN PRAKTIESE VOORSTELLE}

Indien die insigte wat die voorafgaande verkenning bied, naas die huidige praktyk rakende gebed in die liturgie geplaas word, roep dit etlike vrae op. So byvoorbeeld kan tereg gevra word watter invloed dit sal hê op die nie so onbekende gereformeerde liturgiese benadering van sekere liturge om tot 'n dag lank voor te berei aan 'n preek, maar weinig of selfs niks voorbereidingstyd aan liturgiese gebed te bestee nie. Tereg kan ook gevra word waarom vaste gebedsvorme in die gereformeerde erediens in 
Suid-Afrika in die algemeen beskou nie so gewild is soos die vrye tipe gebed nie. ${ }^{6}$ Dit sou nie onvanpas wees om te wonder tot hoe 'n mate die verbruikerskultuur in hierdie verband rigtinggewend is en watter kontrakulturele rol gebed in die liturgie behoort te vervul nie.

\subsection{Roetemerkers}

Uit die voorafgaande verkenning kan die volgende roetemerkers samevattend weergegee word met die oog op die ontwikkeling van 'n teorie vir die praktyk, en op grond daarvan sal enkele verdere voorstelle aan die hand gedoen word:

- $\quad$ Die huidige liturgiese bewegings en teenbewegings het 'n duidelik invloed op die wyse waarop liturgiese gebed hanteer word. Dit beteken dat liturge in die toekoms breër as slegs die tradisionele Sondagliturgie bydraes sal moet lewer en reeds lewer en juis sal moet help om op 'n sinvolle wyse vir die bidders vorm aan hierdie "opkomende" gebedspraktyke te gee en terselfdertyd te sorg dat dit op ' $n$ teologies verantwoordelike wyse ingeklee word. Ten dele is die inagneming van die spiritualiteitstipes in die erediens alreeds ' $n$ poging om die verskillende behoeftes van mense te ondervang. Die uitdaging het dus met die voortgaande proses van liturgiese enkulturasie te make, maar is spesifiek op liturgiese gebed toegespits.

- ' $n$ Belangrike deel van die liturgiese bewegings is ' $n$ teenbeweging en herwaardering van tradisionele liturgiese vorme soos die klassiek gereformeerde diensorde waarvan die vrye gebedstipe 'n integrale deel uitmaak. 'n Pleidooi vir wegdoening met die vrye gebedsvorm word dus geensins gelewer nie, maar eerder 'n pleidooi vir goeie voorbereiding van ook die vrye gebede.

- Klem op die ontmoetingskarakter van die liturgie vra nuwe aandag vir vaster gebedsvorme wat sinvol vooraf voorberei is en die gemeente sinvol in 'n ontmoeting lei eerder as slegs 'n dialoog wat karakteristiek is van die vrye tipe gebed. Hier kan gedink word aan die nie-verbale aspekte van gebed soos stilte, liggaamshouding en sekere rituele soos die aansteek van 'n kers wat hierdie ontmoetingskarakter versterk.

6 As deel van 'n sogenaamde RDP navorsingsprojek van die outeur wat gesetel is aan die Universiteit van Pretoria word op 'n gereelde basis eredienste uit die Gereformeerde tradisie besoek deur middel van deelnemende observasie en kan hierdie opmerking dus deur 'n observasie van die gevierde liturgiese praktyk gestaaf word. 
- Van vroeg af was daar 'n dinamiese verhouding tussen die gemeente se gesamentlike gebed en individuele gebede van lidmate wat daarin opgeneem is. Hierdie dinamiek word verder geneem in die Psalms (van Dawid) en ook met betrekking tot Christus se gebed en voortdurende intrede by die Vader. Die gebed in die liturgie van die gemeente en van individuele lidmate word dus gebid in Christus wat vir ons intree. Sodoende kan die unieke stemme van 'n plaaslike gemeente in die gebed in die liturgie gehoor word en is as sodanig geraam in Christus se intrede.

- By Jesus se eie wyse van gebed is duidelik sprake van beide kontinuïteit en diskontinuïteit met die bestaande tradisie.

- Soos prediking en die res van die liturgie, werk gebed vormend op erediensgangers in. Soos wat ons bid, word ons wat ons reeds is. Daar is ook ' $n$ inherente spanning in liturgiese gebed met betrekking tot ora et labora; daarom is die teologiese inhoud van gebed in die liturgie belangrik. Inhoudelik kom liturgiese gebed tot uitdrukking op 'n spektrum tussen klag en verlange, en 'n goeie, gebalanseerde teologiese spyskaart behoort hier te funksioneer, wat nogeens groot klem op goeie voorbereiding plaas.

- Daar is 'n dinamiese voortgaande pneumatologiese wederkerigheid tussen dit wat God deur sy Gees in gebed doen en die ontvanklike gesindheid van die bidders.

- Liturgiese gebed is deel van die priesterlike taak van die liturg waarin hy of sy woorde op die lippe van erediensgangers plaas.

- Gebede met 'n vaste vorm in die liturgie is 'n ou en ook Bybelse gebedsvorm wat ook 'n integrale en selfs voorkeurvorm in die gereformeerde tradisie is, alhoewel die vrye gebedstipe ook deel van die gereformeerde liturgiese tradisie is. Beide vaste en vrye gebed het 'n regmatige plek in die gereformeerde liturgie. Die vraag sal wees watter een om watter redes tans domineer en of aanvulling na die ander kant sinvol sal wees. Hierdie studie is van die oortuiging dat aanvulling in ons eie konteks nodig is ten opsigte van goed voorbereide, vaster gebedsvorme as doelbewuste kontrakulturele liturgiese handeling.

- Inhoudelik behoort 'n duidelike en sinvolle verband tussen die inhoud van die gebed, die teologiese inhoude van Skriflesings wat in die erediens funksioneer en die konteks te bestaan. 'n Hermeneutiese vaardigheid soortgelyk aan die vaardigheid wat in die voorbereiding van 'n preek nodig is, is dus noodsaaklik vir die voorbereiding van liturgiese gebed vir beide die vaste en vrye liturgiese gebede ('n vrye 
vorm impliseer nie 'n afwesigheid van voorbereiding nie). Dit beteken dus dat voorbereiding van die liturgie meer behels as slegs die voorbereiding van die preek, wat een onderdeel van die oorkoepelende liturgie is.

Hierdie enkele punte plaas opnuut die fokus op die belang van noukeurige voorbereiding met die oog op gebed in die liturgie. Afhangende van die bepaalde tradisie, sal verskille in die presiese aard van voorbereiding bestaan. Die keuse word hier uitgeoefen om op twee sake te fokus: Eerstens kan gefokus word op die ryke verskeidenheid soorte gebede wat die bestaande liturgiese gebedspraktyk kan verryk en liturge en eredienswerkgroepe kan help om inhoudelik liturgiese gebede voor te berei. Tweedens kan gefokus word op die belangrike priesterlike taak van voorgaan in gebed en die belang van liturge en ander wat in die erediens voorgaan kan help om voor te berei met die oog op die voorgaan in gebed in die liturgie. Ten slotte enkele opmerkings oor beide aspekte:

\subsection{Soorte gebede}

Met die oog op voorbereiding van gebede (vaste en vrye tipes) vir die liturgie, bied die bestaande skat van soorte gebede baie hulp. Sekere soorte gebede is meer gepas vir persoonlike gebed buite die liturgie en pas nie teologies gesproke goed in die liturgie nie. So wys Mulder (1996:3) tereg daarop dat gebede wat in die eerste persoon enkelvoud geformuleer is, nie gepas is wanneer ' $n$ liturg namens die gemeente in die liturgie in gebed voorgaan nie, omdat die gemeente as liggaam versamel is en as sodanig aanbid (vgl. ook Old 2002:4\&5). Mulder (1996:10) is verder van mening dat 'n gebed in die liturgie ophou om 'n gebed te wees wanneer dit in 'n preek oorgaan, ' $n$ blote herhaling is van dit wat alreeds in die preek gesê is, of wanneer dit ' $n$ aankondiging is. "Then it is addressed from you to the people, not from the people to God" (Mulder 1996:10).

Al die moontlike tipes kan onmoontlik nie hier behandel word nie; daarom word na enkele gebedstipes slegs verwys en sommiges kortliks belig. Daar sal byvoorbeeld vir diegene wat voorgaan, die liturg of iemand anders, persoonlike gebed as deel van die voorbereiding tuis of in die kerk wees (Vlaming 2002:11-14). Daar is ook die tradisionele konsistoriegebed wat as deel van die liturgie beskou kan word. Die NG Kerk se Handleiding vir die erediens (Clasen et al. 2010:42) wys op ses fasette van gebed in die liturgie, te wete verootmoediging en skuldbelydenis, aanroeping en lofprysing, epiklese, danksegging, aanbidding en ook voorbidding. Mulder (1996:4-6) en Witvliet en Brink (2004) onderskei op hulle beurt weer tussen die invokasie, kollekta, gebed om skuldbelydenis, epiklese, gebed om 
toewyding, gemeentelike gebed, danksegging ná die nagmaal, litanieë en seën as gebed. Ter illustrasie is die volgende twee gebedsvorme vir verskeie soorte gebed bruikbaar:

- Gemeentelike gebed

Hierdie gebed bring die gemeente en die wêreld voor God. Hier bid die gemeente vir die wêreld. Witvliet en Brink (2004:26) gee 'n basiese struktuur:

(a) Geadresseer aan God

(b) Lof en dank vir wie God is en wat Hy gedoen het

1. deur die wêreld te skep;

2. die wêreld in Christus te verlos;

3. met spesifieke dade van trou aan die huidige gemeenskap; en

4. vir die seker belofte van sy koninkryk wat kom.

(c) Intrede vir wêreldwye en plaaslike nood, insluitende

1. die skepping en ons sorg daarvoor, spesifiek...;

2. die nasies van die wêreld, veral...;

3. ons land en die regering, spesifiek...;

4. ons gemeenskap en wie ons regeer...;

5. die wêreldwye kerk, haar sending en hulle wat in die kerk dien, in die besonder...;

6. die plaaslike gemeente en haar bediening, in die besonder...; en

7. diegene met besondere nood, spesifiek...

(d) Doksologie gerig aan die Drie-enige God, in gemeenskap met diegene wat Hom in die hemel en op aarde loof.

- $\quad$ Litanie

Hierdie gebedsvorm word deur iemand gelei, maar die gemeente antwoord gereeld, byvoorbeeld: 
Litanie in Koninkrykstyd (n.a.v. Matteus 16)

V: Here Jesus, laat u koninkryk kom. Hoor ons gebede. Vanoggend vra ons vergifnis...

G: omdat ons nie van die kruis hou nie.

V: Ons vra om vergifnis...

G: omdat ons nie kans sien om onsself te verloën nie.

V: Ons vra om vergifnis...

G: omdat ons ten alle koste ons lewens wil behou.

V: Here Jesus, laat u koninkryk kom. Hoor ons gebede. Gee vir my die vertroue...

G: om my kruis op te neem.

V: Gee vir my die vertroue...

G: om myself te kan verloën.

V: Gee vir my die vertroue...

G: sodat ek my lewe terug sal kry.

V: Here Jesus, laat u koninkryk kom. Hoor ons gebed:

G: en kom met $U$ engele!

V: Maranatha, kom, Here Jesus.

G: Amen.

\subsection{Voorgaan in liturgiese gebed}

In hierdie laaste deel word enkele belangrike aspekte genoem wat diegene wat in die liturgie in gebed voorgaan, in ag kan neem. Eerstens behoort daar goeie kommunikasie te wees tussen alle deelnemers wat in die beplanning en leiding van die betrokke liturgie betrokke is, sodat daar duidelikheid is oor sake soos die tema van die preek, die sakramente wat bedien word, pastorale aangeleenthede in die gemeente en dies meer. Sodoende kan die gebede sinvol binne die groter geheel van die liturgie van die betrokke Sondag pas. 'n Liturg sal met die oog op gebed in die liturgie ook goed doen om seker te maak dat hy/sy op hoogte is van nuusgebeure deur selfs tot kort voor die aanvang van die diens nog na die nuutste nuusflitse op die Internet te kyk. Goeie kontak met mense in die gemeente (die hartseer, blydskap en dankbaarheid) is net so essensieel vir voorgaan in gebed en voorbereiding van gebede as wat dit vir die prediking is. Thomas Long (2005) merk tereg ten opsigte van die prediking op dat die prediker van die gemeente na die gemeente gaan. Toegepas op gebed in die liturgie kan gesê word dat 'n liturg in die liturgie vanuit die gemeente namens die gemeente bid. Diegene wat in gebed voorgaan behoort self ook gebed te beoefen in die tyd voor die erediens en in voorbereiding daarop. 
Voorgangers kan gerus ook gereeld dink aan die tradisionele kategorieë wat alreeds genoem is, byvoorbeeld danksegging en skuldbelydenis, en dit dan invul met spesifieke sake wat in hierdie kategorieë aan die orde kan kom. Deur die gebede behoort die erediensgangers 'n gebalanseerde dieet van Bybelse temas aangebied te word (Witvliet \& Brink 2004:8). Skrifgedeeltes soos 'n Psalm of die Ons Vader-gebed se struktuur kan goedskiks gebruik word om die gebed te struktureer. Voorgangers kan ook gebede volledig uitskryf, al neem hulle nie geskrewe tekste saam met hulle na die liturgie nie. Verder is dit belangrik om taalgebruik in gebede goed te deurdink. Taal kan familiêr wees maar nie arrogant nie en taal moet verder beide geslagte insluit (Mulder 1996:6-9). Laastens is dit belangrik om deurentyd te onthou dat voorgaan in gebed in die liturgie ' $n$ priesterlike taak is; daarom is die oorgangsinne wat ' $n$ bepaalde gebed aankondig of inlui van groot belang om erediensgangers te bemagtig dat hulle die gebed as hulle eie sal toe-eien, byvoorbeeld: "Sommige van ons is vanoggend hier met blydskap in ons harte. Ander weer het trane wat hulle wegsteek. Kom ons bring beide ons hartseer en blydskap voor God met die volgende gebed. Kom, laat ons bid."

\section{TEN SLOTTE}

In hierdie verkenning was die sentrale objek van ondersoek gebed in die liturgie, en die eksplisiete doel was om inkultureerbare riglyne vir die hedendaagse liturgiese praktyk te formuleer. In essensie word die voorafgaande roetemerkers, die soorte gebede en die riglyne vir voorgangers aangebied om die huidige praktyk met betrekking tot gebed in die liturgie te verryk en dit as sodanig vir beide voorgangers en erediensgangers meer betekenisvol te maak.

\section{BIBLIOGRAFIE}

BARNARD, M. 2000. Liturgiek als wetenschap van christelijke riten en symbolen. Amsterdam: Vossiuspers.

2006. Liturgie voorbij de liturgische beweging. Over 'Praise and Worship', Thomasvieringer, kerkdiensten in migratenkerken en ritualiteit op het internet. Zoetermeer: Uitgeverij Meinema.

Barnard, M. \& Post, P. (Reds.). 2001. Ritueel bestek. Antropologische kernwoorden van de liturgie. Zoetermeer: Meinema. 
BRIENEN, T.

1987. De liturgie bij Johannes Calvijn. Kampen: Uitgeverij De Groot Goudriaan.

Clasen, F. Et Al. (Reds.).

2010. Handleiding vir die erediens. Wellington: Bybelmedia.

IMMINK, G.

2011. Het heilige gebeurt. Praktijk, theologie en traditie van de protestantse kerkdienst. Zoetermeer: Meinema.

LONG, T.G.

2005. The witness of preaching. Second Edition. Louisville, KY: Westminster John Knox Press.

MCKeE, E.A.

2003. Reformed worship in the sixteenth century. In: L. Vischer (ed.). Christian Worship in Reformed churches past and present. (Grand Rapids/ Cambridge: William B. Eerdmans Publishing Company), pp. 3-32.

MULDER, T.J.

1996. So you have to... lead in prayer. Grand Rapids, MI: Faith Alive Resources.

MülleR, J.

1990. Die erediens as fees. Pretoria: NG Kerkboekhandel.

OLD, H.O.

2002. Reformed accoring to Scripture. Revised and expanded edition. Louisville, KY: Westminster John Knox Press.

OSMER, R.R.

2008. Practical Theology. An introduction. Grand Rapids, MI: W.B. Eerdmans.

Post, P.G.J.

2004. Over de historiese referentie in de rooms-katholieke 'hervorming-van-dehervormings-beweging'. Jaarboek voor liturgie-onderzoek 20: 73-88.

2006. Liturgische bewegingen. Thema's, trends en perspectieven in tien jaar liturgiestudie. Een literatuurverkenning 1995-2005. Zoetermeer: Uitgeverij Meinema.

2010. Voorbij het kerkgebouw. De speelruimte van een ander sacraal domein. Heeswijk: Uitgeverij Abdij van Berne.

2011. Profile of pilgrimage: On identities of religion and ritual in the European public domain. Studia Liturgica 41(2): 129-155.

SMIT, D.

2009. Ontdek die eie aard van Gereformeerde erediens. In C.J. Wepener \& I.J. van der Merwe (reds.). Ontdekkings in die erediens. (Wellington: Lux Verbi.BM), pp. 87-108. 
StRINGeR, M.D. 2005. A sociological history of Christian worship. Cambridge: Cambridge University Press.

TAFT, R. 1993. The liturgy of the hours in east and west. The origins of the divine office and its meaning for today. Collegeville, MN: The Liturgical Press.

TAFT, R.F.

1999. Comparative liturgy fifty years after Anton Baumstark (d. 1948): A reply to recent critics. Worship 73(6): 521-540.

TRIPP, D.K.

1996. Daily prayer in the Reformed Tradition: An initial survey. Cambridge: Grove Books Limited. Joint Liturgical Studies 35.

Van Der Merwe, I.J. 2009. Tien hedendaagse liturgiese skuiwe. In: C.J. Wepener \& I.J. van der Merwe. Ontdekkings in die erediens. (Wellington: Lux Verbi.BM), pp. 250-253.

VAN TONGEREN, L. 2001. Bidden in stilte en in eigentijdse taal. In: M. Barnard \& P. Post (reds.). Ritueel bestek. Antropologische kernwoorden van de liturgie. (Zoetermeer: Meinema), pp. 200-204.

VLAMING, N.L.M.

2002. Laat ons bidden... Een handreiking bij de gebeden in de zondagse eredienst. Zoetermeer: Uitgeverij Boekencentrum.

WARE, C.

1995. Discover your spiritual type. The Alban Institute.

WeGman, H.A.J.

1991. Riten en mythen. Liturgie in de geschiedenis van het christendom. Kampen: Uitgeverij Kok.

Wepener, C.J.

2006. The object and aim of multi-disciplinary liturgical research. Scriptura 93: 384-400.

2007. Doop en nagmaal - rituele waardeur God mense verander. Die betekenis van die sakramente. In: C. Jones (red.). God praat leef luisterryk. Vir gesprekke oor sensitiewe kwessies. Wellington: Bybelkor

2009a. From fast to feast. A ritual-liturgical exploration of reconciliation in South African cultural contexts. Leuven: Peeters Pers. Liturgia Condenda 19.

2009b. Ontdek eietydse tendense en uitdagings rondom die erediens. In: C.J. Wepener \& I.J. van der Merwe (reds.). Ontdekkings in die erediens. (Wellington: Lux Verbi.BM), pp. 181-194. 
2011a. Nuwe tendense buite-om die erediens van die 21ste eeu. NGTT 52 (1\&2): 257-271.

2011b. Soos 'n blom na die son draai. Wellington: Bybelmedia.

Wepener, C.J. \& Cilliers, J.H.

2004. 'In herinnering aan die kinders... wat aan honger en koue moet sterf': Liturgie in 'n konteks van armoede. NGTT 45(2) (Supplementum): 364-372.

WitVliet, J. \& Brink, E.

2004. Prayers of the people. Patterns and models for congregational prayer. Grand Rapids, MI: Calvin Institute for Christian Worship \& Faith Alive Christian Resources.

Keyterms

Prayer

Liturgy

Practical theology
Sleutelwoorde

Gebed

Liturgie

Praktiese teologie 